\title{
Black Aesthetic/s as divine lover of No End In Sight:
}

\section{the progenitors of world altering resiliency}

\author{
esperanza spalding ${ }^{1}$ \\ 1 Music, Harvard University, USA \\ Received: 18 February 2021 Accepted: 26 February 2021 Published: 20 April 2021 \\ Editors: Marisol Norris, Leah Gipson Reviewer: Britton Williams
}

\section{Abstract}

This artistic response centers Black aesthetical alchemy as a source of radical healing and liberation. Recognizing the brutal strain of a white supremacist caste system, the author situates resilience as a r/evolutionary spiritual trait and innate cultural praxis. Black life and wholeness is explored through intimate acts of place-making, reclamation, and creation.

I write this as a black-identifying 36 year old woman, living in the United States, born and branched in Portland, OR, to a family tree expressing Nigerian, Camaroonian, Scottish, Welsh, British, Norwegian, Senegalese, and Irish lineages (among others I'm sure).

and/or

an environmental adaptation that becomes a r/evolutionary spiritual trait - the power and capacity to alchemize the alienation of being Black within our uniquely brutal strain of a white- supremacist caste system. i.e. the power to alchemize all that into

*a medicine ineffable to those it is not intended for. a medicine that grows fervently and organically from where it is most needed...

and/or

the rhythm of that neath-the-surface rupture and lightning bolt pattern as the crack gives and the whole dam breaks...

and/or 
maybe the only force that can make the home place/space for us -and the lineages traveling with us through DNA and social entanglement- between the realities of not being able to go back "home", and the re-cognition that we are in fact not entitled to claim as "ours" the unceded tribal lands which comprise every square inch of these United States...

and/or

when with all that, we are still born here, our children will be born here, and we are neither indigenous, nor immigrant, nor lord, nor learned in relating to the land as 'commons', nor neither not neither nor nor nor neither neither neither (and Black Aesthetic/s laugh raucously at such wanton repetition of their incantation) ....and then too, a re-cognition of the truth that our western ways of living -as the coveted life-force in this zombie body of industrial-capitalist- consumerism- are about to expire, and then in staggers No End In Sight...

and/or

the means for devising new means for relating to this No End In Sight

as I personally lean into this fractal fracture of beliefs, and great-grand-parents' dreams, and identity as land "owner", and surrender to the guidances from that deep been-knowin place (along with friends, family, peers, employers, neighbors, listeners, students, mentors) for the means for devising new means for relating to this No End In Sight...

and/or

the answer to: what is strong enough, solid enough, pliable enough, ours enough, already-in-us enough, to meet and temper our woeful and urgent bridging-work? what love-born force is abundant enough to bring forth the resiliency needed to enwhole** our psyches, bodies and relationships, as we make sense with these soundings to historical depths un-fathomable by the instruments of reparation or reconciliation???...

and/or

an inherited spiritual technology of resiliency you, or I, or our children would actually want to be implicated and involved in.

an innate cultural praxis of resiliency you, or I, or our children would actually want to be implicated and involved in...

and/or

the bridge - or surely a foundational support of it- we construct through remembering, through trusting, through KNOWING, that the tension of neither/nor dilates a portal through which breathes and cries, exudes and exhumes, the meta-alchemy of: making the most glorious place out of no place...

and/or 
knowledge that this world-altering alchemical power only emerges when Black Aesthetic/s and No End In Sight meet and rub vigorously upon, and with-in each other, and surrender to the eros and power crackling between their weighty, real physicalities...

and/or

because no truly liberatory and enwholing song, music-style, or dance can be born in a state of denial about one's own pain. nor can it be born by succumbing to the temptation -even when succumbed to with loving, liberatory, community-tending intentions- of "solutions" offered by the colonial-capitalist cosmology.

i.e. if black people just had enough land of "our" own to build organic farms and communes... (this coming from yours truly who is presently working on such a project, and navigating the complications addressed herein)...

and/or

the real definition of "enwhole"

$* *$ enwhole - a process by which something makes itself whole, makes itself heal.

and/or

when Black Aesthetic/s and No End In Sight embrace as lovers, they kindle a hearth, and build a home dimension, that not only ushers in the wandering Black-spirit, but often other adjacent lineages traveling with us through DNA and social entanglement...seeing as, these other colonial-homes we've inherited reek of: psychosis, denial, and death, and how can there be love when there's denial? worsely, denial of the fact that we, along with everything else -even empires and caste systems- will someday die?...

and/or

is Black expressive genius the only earthly privilege that doesn't: commit genocide, deny another their wholeness to justify its beauty, "own" the sacred water, ask what god you pray to, need constituencies of poor working bone to bone to raise its children above others, hide its sexual agenda, need an origin story directly linked to an image of god, need permission from the crown or bible, collect a sack's worth of scalps to buy itself a little land with the bounty payouts, erect a building to em-body itself in perpetuity, need history or science to prove it's good/real/needed/lovable, need "freedom and justice for all" before it can gift its potential to the world, default to occupying the house of dispossessed peoples so its abuser can continue to profit via denial of another's rights - to keep you in the promise of its protection?...

aaaaand

One of my Welsh ancestors is taking control of the keyboard now, and wishing to w/rite ...and, oh god, what they got the audacity to say about Black Aesthetic/ s!?!?!?!?!:

'you don't know me specifically, but i am part of you, and love you. and out of that love please, I beg you: please please please don't make the same mistake we made when we sunk anchor in the knowing that we couldn't go back home. -once we'd been ferried far enough 
from burning temples, and memories of our beheaded kinfolk, and remembered with each generation, we were stuck here under the 'mercy' of empires paving our way to pave theirs. (moans and groans) if we could if we would have.... called a fresh cosmology up upon us, or the old-old world ways of knowing, growing, being in soft-footed fugitivity, in guest-hood...

but ......we bloodily initiated into this one-way valve of "white" cult, "ownership" cult, "ours" cult. our precarity was fertile ground for reciprocity with other ways and walks among the not "ours"....if our lives/works had surrendered to the death already died back "home", and allowed that rebirth as daily practice of permission-asking, gentle walking, custodianism, or self tendering to foster Our wholeness as that long lost home-ness-... but... here we are now, sighing in your blood, the un-digested blows upon us currenting all through us.

you once heard someone teach "the abused can not heal as long as they continue to play out their abuse on another" ...well...well....so...what are we gonna do? but yeah, about the Black Aesthetic/s. ...woo! if you could hear just what that sounds like from inside your blood!! Its ALWAYS speaking, holding us to looking at ourselves woven so tight through/to/with your blackness... humming this song that goes like: "please please don't even try, cause only I, I said only I, can make a place in no place and meanwhile not commit genocide, deny another their wholeness to justify my beauty, "own" the sacred water, ask what god you pray to, need constituencies of poor working bone to bone to raise my children above others, hide my sexual agenda, need an origin story directly linked to an image of god, need permission from the crown or bible, collect a sack's worth of scalps to buy myself a little land with the bounty payouts, erect a building to em-body myself in perpetuity, need history or science to prove I'm good/real/needed/lovable, need "freedom and justice for all" before I can gift my potential to the world, orrrr default to occupying the house of dispossessed peoples so my abuser can continue to profit via denial of another's rights."

we've been learning in here, in you...listening in here, in you... and can say beyond the shadow of your doubt:

you've got to let that zombie's body decompose! -therein lies (???'s) gift of what-one-must-become-to-truly-tend-the-wounded-lands/peoples/waters-that-find-us-through-love-again-andagain-through-the-very-soles-of-your-feet-wherever-you-happen-to-stand.

when you walked the Tygh Valley hills praying to be of use to ancestors and peoples of that land, I heard this vibrate back: 'if you walk a way paved by colonizer cosmology, there is no peace or healing or liberation for any of us. other benevolences are working via your own aesthetic. don't sell the power of their curriculum... for any thing'

and lastly -and I know i've already taken up so much space, sorry, it's still a habit- but lastly:

i beg you: don't forget us in your prayers, rituals, spirit-dialogues.

your own "white" ancestors are not not part of it, yet are quite lost in here, and in need of deep-healing too (which, to put it bluntly,... only you can do)'

and/or

the crimes that forged No End In Sight are many. Black Aesthetic/s is the archivist and perennial gardener, cultivating themselves new seed, to flower, to fruit, to seed, to flower, to fruit, to seed, to flower, to ... thrive squarely in the shit and corpse and mine-pit of their togetherness...

and/or 
the magnanimity of their love... again and again allows the ancestral lineages of the perpetrators, allies, enablers, and accessories of tho/ese crimes to enter the house and receive the gift of

*a medicine ineffable to those it is not intended for. a medicine that grows fervently and organically from where it is most needed...

and/or

there is no escape, so rather than investing in futile faux-scape through superiority, through domination, through pseudo-Christian philosophy, stead of THAT: here's a portal of alternativity you enter right through the dick-hole of this reality. it receives us into the neutral-womb matrix of liberatory wisdom, from where, for instance, the historically recognized buddhas have reported: "when all is consumed in a great fire, this, my land, remains safe and tranquil"

and/or

"they stole it, but you must return it"

(to yourself and ...-sheeeeyt-...literally everyone else)

$\cdots$

and/or

the ask to prepare for further than our present options...

and/or

it knows it cannot stay curled up in ANY promise of "home" because that would atrophy the womb-tone which pushes life through her most impossible birth canal of: all necessary transformations. so it pushes, and screams, and grows into this world, and births who/what is most needed next...

and/or

it foretells a way of finessing our co-relationed future where Black and/or any people's liberation doesn't cost the continued dispossession of Native peoples...

and/or

essence of the only member of this fucked-up family with the practiced talent to sing the song, and embody the gospel of how a people interceded, and halted the re-enactment of the evil- ness exacted on them.

-esperanza (irma nejando) spalding

February, 2021

Portland, OR 


\section{About the author}

Esperanza Spalding aims to ignite and portray various hues of vital human energies through composition, singing, bass playing and live performance, with the intention of offering these sound-energies as an aide for connecting with latent portals of unity consciousness and health. She has aptly named her musical style "what it is". A lover of all music, especially improvisation-based musics emerging from black American culture, and a fledgling devotee of/to their unique liberatory powers, Esperanza's musical aesthetic is prismatic. She is currently exploring music as healing technology, and how principles of receptive formlessness and fecundity may be expressed and embodied through sound/ song based performance. Ample archives of accolades and commentary relating to Esperanza's previous works may be found through an internet search. 